\title{
ILLNESS COGNITIONS, DOCTOR-PATIENT COMMUNICATION AND PRESCRIPTION ADHERENCE AMONG FIRST DIAGNOSED HYPERTENSIVE PATIENTS FROM A RURAL TEACHING HOSPITAL IN SOUTH AFRICA
}

\author{
K Peltzer \\ Health Behaviour Research Unit, University of the North \\ Corresponding author: peltzerk@mweb.co.za
}

\section{LB Khoza}

Associate Professor, Department of Nursing, University of Venda for Science and Technology

\section{ME Lekhuleni}

Lecturer, Department of Nursing, University of the North

\section{Alberts}

Associate Professor, Department of Medical Sciences, University of the North

\author{
J Mekwa \\ Professor, Department of Nursing, University of Cape Town
}

\section{E Sethosa}

Research mentor, Population Council, Johannesburg

Keywords: black South Africans; doctor-patient communication; hypertensives; illness cognitions; medication adherence

\begin{abstract}
This study examines the relationship between illness cognitions, doctor-patient communication and the use of prescribed medication among patients first diagnosed with hypertension in the outpatient department of a rural South African teaching hospital. The sample included two men and 43 women, in the age range of 38 to 85 years, $(M=60.5$ years, $S D=11.5$ years); 14 (31\%) were 65 years and above. Outcome measures included doctorpatient communication, recall interview, illness cognitions, and anthropometrical measurements. From the 45 patients studied 23 (51\%) were not adherent with prescription medication. Major findings were that doctor-patient communication, most illness cognitions, and healthy behaviour of the patient were not associated with adherence behaviour. Perceived stress and the belief of incurability of hypertension were, however, related with adherence behaviour. Patients frequently mentioned mental and environmental stress as causative and management beliefs. On the contrary, the treating physicians did not allude to mental and environmental stress. Physicians gave little lifestyle health education. In instances where it was given, most patients seemed to practice it.
\end{abstract}

\section{OPSOMMING}

Hierdie studie ondersoek die verwantskap tussen siekte-kognisies, dokter-pasiënt kommunikasie en die gebruik van voorskrifmedisyne onder pasiënte wat die eerste keer met hipertensie gediagnoseer is, in die buitepasiëntafdeling van ' $n$ landelike Suid-Afrikaanse opleidingshospitaal. Die steekproef het twee mans en 43 vroue, binne die ouderdomsgroep 38-85 jaar inges/uit ( $M=60.5$ jaar, $S=11.5$ jaar); 14 (31\%) was 65 jaar en ouer. Uitkomsmetings het dokter-pasiënt-kommunikasie, herbesoek-onderhoude, siekte-kognisies, en antropometriese metings inges/uit. Van die 45 pasiënte wat bestudeer is, het 23 nie gehoor gegee aan hul voorskrifmedikasie nie. Die belangrikste 
bevindinge was dat dokter-pasiënt-kommunikasie, die meeste siekte-kognisies en gesonde gedragswyses van die pasiënt, nie geassosieer was met gehoorsaming van voorskrifte nie. Stres wat waargeneem is en die oortuiging van dat hipertensie ongeneesbaar is, hou egter verband met die gehoorsaming van voorskrifmedisyne. Sielkundige en omgewingstres is dikwels deur pasiënte genoem as oorsaaklike en beheerbare oortuigings, maar nooit deur die geneeshere wat hierdie pasiënte behandel het nie. Die geneeshere het min riglyne ten opsigte van gesonde lewenswyses verskaf. Indien dit wel verskaf is, het dit geblyk dat die meeste pasiënte dit nagevolg het.

\section{INTRODUCTION}

The proportion of deaths due to chronic diseases of lifestyle amounts to $24.5 \%$ of all deaths of the South African population and $28.5 \%$ of these deaths are between the age of 35-64 years (Steyn, Fourie \& Bradshaw, 1992:227f.). The major causes of death contributing to these figures were cerebrovascular diseases $(7.2 \%$ of all deaths) and ischaemic heart disease $(8.7 \%$ of all deaths). An overall of 4.88 million South Africans used to smoke, the largest group of smokers being Black males (2.6 million). Regarding hypertension, 5.5 million South Africans had pressure above 140/90 mmHg; again the largest group were Blacks (3.0 million). Regarding hypercholesterolaemia and raised low-density lipoprotein cholesterol levels, 4.8 million and 3.1 million South Africans respectively had an increased risk for ischaemic heart disease, blacks having the lowest levels (ibid.).

Hypertension has a high prevalence in all language groups in South Africa (Edwards, 1992:105) such as in a black community aged 15-64 years in the Cape (9.2\% males and $12.9 \%$ females) (Steyn, Fourie, Lombard, Katzenellenbogen, Bourne \& Jooste, 1996:758), among urban Zulus (25\%) and rural Zulus (9.4\%) (Seedat, Seedat \& Hackland, 1982:256) and among a black population 25 years and older in Qwaqwa (22.1\% in males and $34.5 \%$ in females) (Mollentze, Moore, Joubert, Oosthuysen, Steyn, Steyn \& Weich, 1993:50). A nationally representative survey in South Africa (Department of Health, 1998:15f.) showed that among persons above 15 years $11 \%$ of men and $13 \%$ of women were found to either have a blood pressure above $160 / 95 \mathrm{mmHg}$ or were taking appropriate medication to lower their blood pressure. A calculation based on these prevalence rates and the census figures published for the South African population 15 years and older leads to an estimate of about 3.3 million hypertensive people in the country. Overall, fewer hypertensive men (9\%) than women (23\%) are aware of their condition.

Similarly, fewer hypertensive men in non-urban areas know that they suffer from the condition than their urban counterparts. This highlights that non-urban hypertensive males are the group with the most undiagnosed hypertension in the country and that they should be targeted to improve the diagnosis rate. This poor level of diagnosis in men is reflected in the low rates of men ( $11 \%$ compared to $28 \%$ of women) who take appropriate drugs for hypertension. Consequently, only $9 \%$ of all men with hypertension had controlled blood pressure $(\mathrm{BP}<160 / 95 \mathrm{mmHg})$, compared to $23 \%$ of hypertensive women. This is still a very low level of control and highlights the need to improve hypertension control in the country if premature death and disability are to be prevented. A more disturbing finding is that the control of hypertension in young patients is far worse than that achieved in older hypertensive patients. Young hypertensive patients require good control even more than older patients to prevent organ damage while they are still part of the labour force of the country. The worst level of control for men was reported in the African group, while for women it was found in non-urban African women (ibid.).

Patient drug use behaviours and adherence have been the focus of much research over the years. DunbarJacob, Dwyer and Dunning (1991:32) indicate, in a review of research done in the eighties, that antihypertensive medication adherence approximates $64 \%$. WHO (1993:12f.) states that 50\% of patients newly diagnosed with hypertension fail to make a referral appointment. As many as $50 \%$ of patients seeking treatment drop out of care within a year. Nyazema (1984:551) found that in Zimbabwe hypertensive or diabetic patients had not complied with follow-up appointments since over $60 \%$ lacked comprehension of their disease and the use of the medicine prescribed to them. 
Esunge (1991:292) identified the following factors in rural Cameroon that appeared to affect hypertensive patient adherence: free medication, free hospital visits, free transportation, open discussion with medical staff, use of a common dialect, and politeness of medical staff. Unger (1995:41) notes that the communication between doctors and their hypertensive patients still suffers from a number of shortcomings owing to ignorance and misconceptions on both sides as well as poorly defined mutual goals. Anthropological research in clinical contexts has shown that differences between patient/practitioner models of health and illness can be the source of many problems in complying with treatment and that the patient's view of his or her own illness is important in the choices of treatment and therefore adherence (for example Blumhagen, 1980:197). Patel and Taylor (2002:40) also note that patients' acceptance of medical advice and information may be influenced by their subjective beliefs about their health condition; therefore, it is essential that their beliefs be taken into account when giving health advice or medical treatment. Coleman (1985:69) identified that four major components are involved in physician behaviour that may impact on patient adherence with treatment regimens: compassion, communication, activating patient self-motivation and shared responsibility with the patient. Current approaches to enhancing adherence use, inter alia illness cognitions and quality of patient-provider communication (Garfield \& Caro, 1999:502). Furthermore, Weir, Maibach, Bakris, Black, Chawla, Messerli, Neutel and Weber (2000:481) found among American hypertensive patients that those who practice a lower healthy lifestyle also were less adherent with prescription medication. These types of patients included (1) members who are most likely to forget to take medication, likely to be obese, and find it most difficult to comply with lifestyle changes (except for very low rates of smoking and alcohol use), and (2) members who are least likely to take medication, most likely to change or stop medication without consulting their physician (20\%), most likely to smoke $(40 \%)$, and least likely to control their diet (29\%).

The purpose of this research was to examine the relationships between doctor-patient communication, illness cognitions, health behaviours, and drug use behaviour (adherence with prescribed antihypertensive medication). "Communication" has been defined as "a process by which information is exchanged between individuals through a common system of symbols, signs or behaviour" (Ruesch \& Bateson, 1987:5). Leventhal and Nerenz (1985:519) define illness cognitions as 'a patient's own implicit common sense beliefs about their illness'. The term 'adherence' is used to imply the extent to which a person's behaviour (in terms of taking medications, following diets, or executing lifestyle changes) coincides with medical or health advice (WHO, 1993:1).

\section{METHOD}

\section{Research design}

This was a prospective study including 45 consecutive first diagnosed hypertensive patients at a rural teaching hospital in the Limpopo Province.

\section{Sample and procedure}

The sample included two men and 43 women, in the age range of 38 to 85 years, $(M=60.5$ years, $S D=11.5$ years); 14 (31\%) were 65 years and above. The mean years of formal education was 3.7 years ( $S D=3.9$ years). Most of them $(41 ; 91.1 \%)$ came from the village and some (4) were from an urban area. Twenty-six (57.8\%) were married or lived with a partner and 19 were widowed/single/divorced. Almost all $(41 ; 91 \%)$ belonged to the ethnic group of Northern Sotho, two were Venda and two Tswana. The major religious denominations were Apostolic and Zion Christian Churches (42.2\%), followed by Protestant type and Roman Catholic Churches (33.3\%), traditional or African religion (17.8\%), and other (6.7\%). Two rated themselves as quite well-off, 26 as not very well-off, 17 as quite poor, and none indicated to be wealthy.

Permission was obtained from the University of the North Ethics Committee and the Northern Provincial Health and Welfare Department.

All consecutively first diagnosed hypertensive patients $(\mathrm{N}=45)$ were interviewed in the outpatient department for a period of seven months. Before consultation, the suspected hypertensive patient was identified from the files and asked for formal consent to participate in the study. Then the patient was accompanied by one of the researchers to the consultation. The consultation was observed, scored and tape recorded. Thereafter, 
an interview was conducted and a questionnaire was administered face-to-face with the patient. This included a recall interview on the doctor-patient communication.

The questionnaires were translated and back translated by bilingual experts in the major languages used in the study. The schedule was field tested before the survey and modified where necessary. After six months, all patients $(\mathrm{N}=45)$ were interviewed again at their homes to assess adherence.

\section{Measures}

(1) A 46 item scoring key for the doctor-patient communication (Boesch, 1988:210ff.). Items include for example: "How does the doctor start the consultation?", "Symptom question concerning cause", "Explaining of cause by doctor", "Personal question related to symptom or other health question", and "Explanation of treatment and medicine by a doctor".

(2) A recall interview of the patient on the consultation (Boesch, 1988:188f.).

(3) Eight items on demographic and socio-economic data and three items on illness perceptions: 1) subjective severity of illness, 2) curability, and 3) fears about the consequences of having hypertension.

(4) The Problem Portrait Technique on illness cognitions (causative and management beliefs) (MacLachlan, 1997:158ff.).

(5) Four healthy behaviours (Steptoe \& Wardle, 1992:485).

Smoking or taking snuff was assessed with eight response options that were subsequently reduced to four categories: no smoking, less than one cigarette per day, 1-10 per day, 10 or more per day (8 items) (Cronbach alpha $=.67$ )

- Alcohol consumption was measured by asking participants which of the following terms best described them: non-drinker, special occasions drinker, occasional and regular drinker. Occasional and regular drinkers were asked on how many days over the last two weeks they had had a drink, and how many drinks they had consumed on those days. These data were used to derive four categories of alcohol consumption: none, very occasional, fewer than one drink per day, and more than one drink per day over the past 14 days ( 6 items) (.54).

- Physical exercise was assessed by questions concerning exercise over the last two weeks, the type of exercise, and the number of sessions carried out. Three categories of exercise were derived from this information: none, one to four sessions in the past 14 days, and five or more sessions (4 items) (.67)

- Eating behaviour was assessed by questions about the frequency of having breakfast, between-meal snacks, red meat, fruits, salt, and by asking about conscious effort to avoid fat and cholesterol in the diet and to eat foods that are high in fibre on a Yes/No format (11 items) (.58).

(6) Anthropometrical measurements and blood pressure was taken three times seated, in intervals of 20 minutes (results were then averaged).

\section{Data analysis}

Discriminant analysis, Chi-square and the student ttest were used to compare the adherent and non-adherent patient groups using SPSS version 10 .

\section{RESULTS}

\section{Drug adherence}

From the total sample of 45 followed up at six months after the first diagnosis, $22(48.9 \%)$ had, by self-report, taken their medication for 30 times, 14 (31.1\%) for 29 or less days and nine (20\%) had not taken any antihypertensive drugs in the past month. Adherent participants were those individuals who self-reportedly took their medications every day as medically prescribed during the 30-day reference period (Brown \& Segal, 1996:906).

\section{IIIness perception}

Thirty $(66.6 \%)$ rated their illness to be very severe and $15(33.3 \%)$ as not being severe. Almost half of the patients $(21 ; 46.7 \%)$ believed that their hypertension was incurable, eleven (24.4\%) felt it could be cured 
with medication and $13(28.8 \%)$ indicated that they would not know how long the sickness would last. There was a significant difference between the adherent and non-adherent groups, namely that the adherent group held more often the belief that hypertension was incurable $(68.2 \%)$ whereas only $26.1 \%$ of the non-adherent group felt likewise $\left(X^{2}=8.006, p<.005\right)$. About half $(51.1 \%)$ feared death, ten (22.2\%) a stroke and eleven (24.4\%) expressed no opinion.

\section{IIIness cognitions}

Table 2 shows group means, standard deviations and significance tests of hypertensive causative beliefs from the Problem Portrait Technique (PPT) rated from 0 to 10 indicating the importance of the behaviour (10 being most important) as well as frequency of agreed responses (in percentage) for the adherent and nonadherent groups.

Table 1: BMI, blood pressure, and doctor-patient communication by drug adherence

\begin{tabular}{|l|l|l|l|}
\hline Variables & $\begin{array}{l}\text { Adherent } \\
(\mathrm{n}=22) \mathrm{M}(\mathrm{SD})\end{array}$ & $\begin{array}{l}\text { Non-adherent } \\
(\mathrm{n}=23) \mathrm{M}(\mathrm{SD})\end{array}$ & $\begin{array}{l}\text { Univariate F- } \\
\text { ratio }\end{array}$ \\
\hline Body Mass Index (BMI) & $30.6(6.0)$ & $29.7(5.9)$ & .244 \\
\hline Waste-Hip ratio\# & $.91(9.2)$ & $.92(9.1)$ & .038 \\
\hline Mean systolic blood pressure & $172.9(17.8)$ & $174.2(18.4)$ & .336 \\
\hline Mean diastolic blood pressure & $104.3(9.3)$ & $106.4(11.6)$ & .988 \\
\hline Doctor-patient communication score & $13.16(5.41)$ & $13.89(4.04)$ & .215 \\
\hline Messages given by doctor & $4.95(1.68)$ & $5.22(1.39)$ & .291 \\
\hline Messages recalled by patient & $2.68(0.82)$ & $3.06(0.87)$ & 1.781 \\
\hline
\end{tabular}

\#men: $M=.97(S D=3.7) ;$ women=.91 $(S D=8.2)$

\section{Blood pressure and doctor-patient communication}

Table 1 indicates discriminant analysis with Body Mass Index (BMI), blood pressure levels, doctor-patient communication and drug adherence behaviour.

The mean body mass index was at first diagnosis, in both adherent and non-adherent groups, around 30; the mean systolic blood pressure about 172 and the mean diastolic blood pressure 105 . The mean ratings for the importance of various health behaviours (rating from 0 to 10) were with a mean of about eight, which is relatively high. There were no significant differences between the two groups. The health practitioner-patient communication score was similar in both adherent and non-adherent patients. About five messages per session were given to both groups at the first diagnosis of hypertension. The messages recalled were between 2.7 and 3.1. Examples for messages given and recalled are given in Appendix I.
The five most important causes as perceived by the participants were salty food, mental stress, fatty food, smoking and drinking alcohol, in that order. The adherent group perceived mental stress and genetics to be more important causes than the non-adherent group. The management strategies from the Problem Portrait Technique were similar in importance and frequency mentioned corresponding to the causative beliefs. The adherent group saw the reduction of mental stress as significantly more important than the nonadherent group. Doing physical exercise and losing weight were perceived to be of low priority (see Table 3).

\section{Healthy behaviour and lifestyle advice}

Table 4 indicates various healthy behaviours of the participants. (Table 4 is on page 64.) 
Table 2: Causative beliefs generated from the Problem Portrait Technique by drug adherence

\begin{tabular}{|l|l|l|l|l|l|}
\hline Causative beliefs & \multicolumn{2}{l}{ Adherent (n=22) } & \multicolumn{2}{l}{ Non-adherent (n=23) } & $\begin{array}{l}\text { Univariate F- } \\
\text { ratio }\end{array}$ \\
\hline & M (SD) & No (\%) & M (SD) & No (\%) & \\
\hline 1. Salty food & $6.2(2.7)$ & $19(86.4)$ & $5.7(3.5)$ & $17(73.9)$ & .380 \\
\hline 2. Mental stress & $6.1(3.8)$ & $16(82.7)$ & $3.6(4.2)$ & $9(39.1)$ & $4.307^{*}$ \\
\hline 3. Fatty food & $4.2(2.8)$ & $16(82.7)$ & $3.8(3.5)$ & $13(56.5)$ & .222 \\
\hline 4. Smoking/taking snuff & $0.8(1.8)$ & $4(18.2)$ & $2.4(3.5)$ & $8(34.8)$ & 3.642 \\
\hline 5. Drinking alcohol & $0.9(2.1)$ & $4(18.2)$ & $2.4(3.5)$ & $8(34.8)$ & 3.224 \\
\hline $\begin{array}{l}\text { 6. Unhealthy diet (white mealie } \\
\text { meal, sugar, modern food, ) }\end{array}$ & $1.2(2.7)$ & $4(18.2)$ & $2.3(3.2)$ & $9(39.1)$ & 1.450 \\
\hline 7. Heredity (only through drugs) & $2.6(3.9)$ & $7(31.8)$ & $0.7(2.2)$ & $2(8.7)$ & $4.140^{*}$ \\
\hline 8. Being overweight & $1.9(3.6)$ & $5(22.3)$ & $1.7(3.4)$ & $5(21.7)$ & .014 \\
\hline 9. Physical stress & $0.5(1.6)$ & $2(9.1)$ & $0.8(1.8)$ & $5(21.7)$ & .544 \\
\hline 10. Lack of exercise & $1.3(2.8)$ & $4(18.2)$ & $1.0(2.7)$ & $2(8.7)$ & .112 \\
\hline 11. Supernatural & 0 & & 0 & & 0 \\
\hline
\end{tabular}

${ }^{* * *} p<.001,{ }^{* *} p<.01,{ }^{*} p<.05$

Table 3: Management beliefs from Problem Portrait Technique (PPT) by drug adherence

\begin{tabular}{|c|c|c|c|c|c|}
\hline \multirow[t]{2}{*}{ Hypertension management } & \multicolumn{2}{|c|}{ Adherent $(\mathrm{n}=22)$} & \multicolumn{2}{|c|}{ Non-adherent $(n=23)$} & \multirow{2}{*}{$\begin{array}{l}\text { Univariate F- } \\
\text { ratio }\end{array}$} \\
\hline & $M(S D)$ & No (\%) & $M(S D)$ & No (\%) & \\
\hline 1. Avoid salty food & $6.3(2.3)$ & $19(86.4)$ & $5.3(3.3)$ & 17 (73.9) & 1.430 \\
\hline 2. Reduce mental stress & $5.2(3.4)$ & $16(62.7)$ & $2.8(3.4)$ & $10(43.5)$ & $5.700^{*}$ \\
\hline 3. Avoid fatty food & $4.7(2.8)$ & $16(72.7)$ & $4.0(3.6)$ & $13(56.5)$ & .519 \\
\hline $\begin{array}{l}\text { 4. Reduce smoking/taking } \\
\text { snuff }\end{array}$ & $0.7(1.7)$ & $4(18.2)$ & $2.1(3.0)$ & $8(34.8)$ & 3.516 \\
\hline 5. Reduce drinking alcohol & $0.6(1.6)$ & $4(18.2)$ & $2.0(2.9)$ & $8(34.8)$ & 3.526 \\
\hline $\begin{array}{l}\text { 6. Avoid unhealthy diet } \\
\text { (white mealie meal, sugar, } \\
\text { modern food, ) }\end{array}$ & $0.8(1.9)$ & $4(18.2)$ & $2.4(3.5)$ & $7(39.1)$ & 3.608 \\
\hline $\begin{array}{l}\text { 7. Heredity (taking } \\
\text { medication) }\end{array}$ & $1.7(2.9)$ & $7(31.8)$ & $0.5(1.7)$ & $2(8.7)$ & 2.535 \\
\hline 8. Reduce weight & $1.4(2.9)$ & $4(18.2)$ & $1.5(3.0)$ & $5(21.7)$ & .025 \\
\hline 9. Avoid physical stress & $0.6(1.8)$ & $3(9.5)$ & $1.3(2.7)$ & $5(21.7)$ & 1.086 \\
\hline 10. Do physical exercise & $1.3(2.7)$ & $4(18.2)$ & $1.0(2.7)$ & $3(13.0)$ & .124 \\
\hline 11. Supernatural & 0 & 0 & 0 & 0 & \\
\hline
\end{tabular}

${ }^{* * *} p<.001,{ }^{* *} p<.01,{ }^{*} p<.05$ 
Table 4: Healthy behaviour among adherent and non-adherent patients

\begin{tabular}{|l|l|l|l|}
\hline Healthy behaviour & $\begin{array}{l}\text { Adherent }(\mathrm{n}=22) \\
\text { No }(\%)\end{array}$ & $\begin{array}{l}\text { Non-adherent } \\
(\mathrm{n}=23) \text { No }(\%)\end{array}$ & $X^{2}$ \\
\hline $\begin{array}{l}\text { Never smoked (or took snuff) } \\
\text { Used to smoke but quit }\end{array}$ & $\begin{array}{l}16(72.7) \\
1(4.5)\end{array}$ & $\begin{array}{l}12(52.2) 1(4.3) \\
8(34.7) \\
2(8.7)\end{array}$ & 5.885 \\
Smoke 1-10 cigarettes per day & $0(22.7)$ & & \\
Smoke 10-20 cigarettes per day & $17(77.3)$ & $12(52.2)$ & 3.413 \\
\hline Breakfast almost everyday & $15(68.2)$ & $9(39.1)$ & 3.813 \\
\hline Try to eat foods with high fibre & $10(45.5)$ & $13(56.5)$ & .551 \\
\hline Avoid fat and cholesterol & $2(9.5)$ & $5(21.7)$ & 3.078 \\
\hline Eat fruits at least once a day & $3(13.6)$ & $6(26.1)$ & 3.757 \\
\hline Limit salt & $1(4.5)$ & $6(26.0)$ & 4.068 \\
\hline Occasional or regular drinker & {$[\mathrm{M}(\mathrm{SD}) 4.0]$} & {$[\mathrm{M}(\mathrm{SD}) 6.8(5.8)]$} & {$[\mathrm{t}=5.677]$} \\
\hline Number of days of alcohol use over the past two & & & \\
\hline weeks (t) & $8(36.4)$ & $9(39.1)$ & 4.273 \\
\hline Perception of being overweight & $6(27.3)$ & $2(8.7)$ & 2.655 \\
\hline Trying to lose weight & $2(9.1)$ & $2(8.7)$ & .002 \\
\hline Dieting to lose weight & $17(77.3)$ & $15(65.2)$ & .795 \\
\hline Exercise over the past two weeks & {$[\mathrm{M}(\mathrm{SD}) 9.4(3.2)]$} & {$[\mathrm{M}(\mathrm{SD}) 10.6$} & {$[\mathrm{t}=3.639]$} \\
\hline Frequency of exercise in past two weeks (t) & & $4.0)]$ & \\
\hline
\end{tabular}

(t) $t$-test

The most frequent healthy behaviours practiced by the patients were: (1) exercise over the past two weeks (71\%), (2) breakfast almost everyday (65\%), (3) never smoked or took snuff (63\%), (4) avoid fat and cholesterol $(50 \%)$, and (5) try to eat foods with high fibre $(45 \%)$, whereas the least frequent healthy practices were: (1) eat fruits at least once a day (15\%), (2) trying to lose weight (18\%), and (3) limit salt intake (20\%). Generally, the adherent group, though not significantly, practised a healthier lifestyle than the non-adherent group.

Table 5 indicates the lifestyle advice as given by the physician to the hypertensive patient at first diagnosis.

The three most frequent instructions given by the physicians were reducing salt, reducing fatty food and to stop drinking alcohol whereas the four least frequent instructions were: avoid stress, lose weight, stop smok- ing and referral to the dietician. Those six patients who were referred to the dietician mainly received the messages of (1) reduce fatty food, (2) reduce salt, and (3) lose weight. Most followed the advice to reduce fatty food $(4 ; 66.7 \%)$, half $(3 ; 50 \%)$ reduced salt, and most $(4 ; 66.7 \%)$ did not lose weight. From the lifestyle advice given by the physicians to the hypertensive patients, most patients generally followed the advice, in particular to stop drinking alcohol and to lose weight. However, they did not stop smoking as advised (see Table 6).

\section{DISCUSSION}

This study assessed doctor-patient communication, illness perception, causative and management beliefs and adherence behaviour with prescription medication in first diagnosed hypertensives attending the outpatient department in a rural teaching hospital in the 
Table 5 : Physician's advice for controlling blood pressure in relation to drug adherence in a descending order of frequency

\begin{tabular}{|l|l|l|l|}
\hline Physician's advice & $\begin{array}{l}\text { Adherent }(\mathrm{n}=22) \\
\text { No }(\%)\end{array}$ & $\begin{array}{l}\text { Non-adherent } \\
(\mathrm{n}=23) \text { No }(\%)\end{array}$ & $X^{2}$ \\
\hline 1. Reduce salt & $15(75.0)$ & $14(73.7)$ & .009 \\
\hline 2. Take blood pressure medication & $11(55.0)$ & $11(57.9)$ & .033 \\
\hline 3. Reduce fatty food & $8(40.0)$ & $6(31.6)$ & .300 \\
\hline 4. Stop drinking alcohol & $4(20.0)$ & $8(42.1)$ & 2.235 \\
\hline 5. Get more exercise & $5(25.0)$ & $2(10.5)$ & 1.386 \\
\hline 6. Lose weight & $3(15.0)$ & $1(5.3)$ & 1.004 \\
\hline 7. Stop smoking & $2(10.0)$ & $3(15.8)$ & .292 \\
\hline 8. Avoid stress & $1(5.0)$ & 0 & .975 \\
\hline 9. Referred to dietician & $3(13.6)$ & $3(13.0)$ & .003 \\
\hline
\end{tabular}

Table 6: Physician's lifestyle advice for controlling blood pressure in a descending order of frequency and patient's practice after a period of six months

\begin{tabular}{|l|l|l|l|}
\hline Physician's lifestyle advice & $\begin{array}{l}\text { MD Advice practiced } \\
\text { No (\%) }\end{array}$ & $\begin{array}{l}\text { MD advice not } \\
\text { practiced No (\%) }\end{array}$ & $X^{2}$ \\
\hline 1. Reduce salt & $18(62.1)$ & $11(37.9)$ & .203 \\
\hline 2. Reduce fatty food & $11(78.6)$ & $3(21.4)$ & .203 \\
\hline 3. Stop drinking alcohol & $8(66.7)$ & $4(33.3)$ & $4.290^{*}$ \\
\hline 4. Get more exercise & $4(66.7)$ & $2(33.3)$ & .021 \\
\hline 5. Lose weight & $3(75.0)$ & $1(25.0)$ & $4.093^{*}$ \\
\hline 6. Stop smoking & $1(20.0)$ & $4(80.0)$ & .077 \\
\hline 7. Avoid stress & 0 & 0 & --- \\
\hline${ }^{*} \mathrm{p}<.05$ & & &
\end{tabular}

Limpopo Province, South Africa. From the 45 patients assessed at first diagnosis and followed-up after seven months, $23(51 \%)$ were not adherent with prescription medication. Similar to another study in South Africa, there was a preponderance of women in this sample (95.5\%). Lunt, Edwards, Steyn, Lombard and Fehrsen (1998:545) found that among 1098 hypertensive clinic attendees in a Cape Town community health centre, $81.7 \%$ were females. Adherent behaviour was associated with the causative beliefs of mental stress and heredity. More especially the non-adherent patients believed that their hypertension was less permanent as opposed to the adherent patients. Lack of chronic- ity limits the importance of following a prescribed treatment (Schoenberg, 1997:176). The causative beliefs of mental stress and heredity in the adherent group lead to more control of mental stress and a focus on prescription medication (since the problem is inherited). Both concepts of mental stress and heredity seem to be contradictory but seem to support pluralistic causative and management beliefs (MacLachlan \& Carr, 1994:119). In line with other research (Patel \& Taylor, 2002:40), patients in this study indicated that modifiable variables were the most common attributions believed to cause hypertension. However, there was no significant relationship to medication adherence. 
Health practitioner-patient communication messages given by the doctor and recalled by the patient, the physician's lifestyle advice, blood pressure level, BMI, most causative and control beliefs, and healthy behaviour of the patient were not associated with adherence behaviour. Mental and environmental stress was mentioned frequently by the patients as causative and management beliefs in this sample, which was similar to what was found among White and West Indian hypertensives (Morgan \& Watkins, 1988:561). However, doctors' lifestyle advice in this sample did not include stress management. In this sample, little was mentioned about supernatural causes and management of hypertension. However, Schoenberg (1997:174) found, among African-American rural elders with hypertension, that the most frequently mentioned means of controlling high blood pressure included avoiding and eating certain foods, losing weight, praying, reading the Bible, taking home remedies and exercising. Generally, physicians gave little lifestyle advice (apart from reducing salt, less than $40 \%$ gave any other lifestyle advice) and also referred only a few cases to the dietician. Bloomfield, Young, and Graves (1993:767) found, among black hypertensives, that their physician had given them (endorsed by the patient) the following advice for controlling blood pressure: (1) reduce salt (68.6\%), (2) lose weight $(47.1 \%)$, (3) get more exercise (35.3\%), (4) stop smoking (27.5\%), and (5) avoid stress (21.6\%). Although in this sample lifestyle advice was not significantly associated with adherence of prescription medication, the majority followed the lifestyle advice given by their physician. This seems to support that physicians should improve their lifestyle health education with hypertensive patients and involve dieticians.

Poor adherence to long-term treatment, both lifestyle modifications and pharmacological therapy, have been identified as the major reasons for inadequate control of elevated blood pressure (Kitler, 1996:5).

An important limitation of this study was that adherence with prescription medication was obtained by selfreports. However, these self-reports were crosschecked by also investigating the hospital files, since patients had to space appointments with the hospital in between their clinic attendance. Moreover, the results of self-reported medication used in other studies indicate that self-reports are good estimates of actual medication taking practices (Brown \& Segal, 1996:908).

The findings of the study further support the suggestion that patient belief systems should be considered when developing interventions and when monitoring patient outcomes. The implication is that health and medical care providers can help to improve adherence with prescribed regimens by helping patients incorporate the regimens into their daily routines such as indigenous terminology for hypertension and lifestyle advice. In addition, health and medical care providers should actively and non-judgementally elicit patient beliefs about causes and treatment.

\section{Acknowledgement}

Funding by the Medical Research Council (South Africa) and the University of the North for this study is hereby acknowledged.

\section{REFERENCES}

BLOOMFIELD, R; YOUNG, LD \& GRAVES, J 1993: Racial differences in perceptions concerning hypertension and its consequences. Southern Medical Journal, 86:767-70.

BLUMHAGEN, DK 1980: Hypertension: a folk illness with a medical name. Culture, Medicine \& Psychiatry, 4(2):197-227.

BOESCH, EE 1988: Doctor patient interaction in Thailand. Saarbrücken: Institute for Social Psychological Development Planning.

BROWN, CM \& SEGAL, R 1996: The effects of health and treatment perceptions on the use of prescribed medication and home remedies among African American and White American hypertensives. Social Science \& Medicine, 43(7):903-917.

COLEMAN, VR 1985: Physician behaviour and compliance. Journal of Hypertension (Suppl), 3(1):69-71.

DEPARTMENT OF HEALTH 1998: South Africa demographic and health survey. Pretoria: Author.

DUNBAR-JACOB, J; DWYER, K \& DUNNING, EJ 1991: Compliance with antihypertensive regimen: a review of the research in the 1980s. Annals of Behavioural Medicine, 13(1):31-39.

EDWARDS, DJA 1992: The challenge of hypertension to South African health psychology: 1. The potential contribution of educational, cognitive and behavioural strategies to prevention and treatment. South African Journal of Psychology, 22(1):105-116. ESUNGE, PM 1991: Patient compliance and the evaluation of drug 
trials for hypertension in rural Africa. Ethnicity and Disease, 1(2):292-294 .

GARFIELD, FB \& CARO, JJ 1999: Compliance and hypertension. Current Hypertension Reports, 1(6):502-6.

KITLER, ME 1996: The changing face of hypertension and antihypertensive agents. Drugs Aging, 8(1):5-11.

LEVENTHAL, H \& NERENZ, D 1985: The assessment of illness cognition. (In: Karoly, P ed. 1985: Measurement strategies in health psychology. New York: Wiley, pp 517-554).

LUNT, DWR; EDWARDS, PR; STEYN, K; LOMBARD, CJ \& FEHRSEN, GS 1998: Hypertension care at a Cape Town community health centre. South African Medical Journal, 88(4):544548.

MACLACHLAN, M 1997: Culture and health. Chichester: John Wiley.

MACLACHLAN, M \& CARR, SC 1994: From dissonance to tolerance: towards managing health in tropical cultures. Psychology and Developing Societies, 6(2):119-129.

MOLLENTZE, WF; MOORE, A; JOUBERT, G; OOSTHUYSEN, GM; STEYN, AF; STEYN, K \& WEICH, DJV: 1993 Cardiovascular risk factors in the black population of Qwaqwa. South African Journal of Clinical Nutrition, 6(1):50-51.

MORGAN, M \& WATKINS, CJ 1988: Managing hypertension: beliefs and responses to medication among cultural groups. Sociology of Health \& IIIness, 10(3):561-578.

NYAZEMA, NZ 1984: Towards better patient drug compliance and comprehension: a challenge to medical and pharmaceutical services in Zimbabwe. Social Science \& Medicine, 18(4):551-554. PATEL, RP \& TAYLOR, SD 2002: Factors affecting medication adherence in hypertensive patients. Annals of Pharmacotherapy, 36(1):40-5.

PELTZER, K; MEKWA, J; KHOZA, LB; LEKHULENI, ME; ALBERTS, M \& SETHOSA, E 2002: Factors at follow-up associated with prescribed medication for hypertensive patients from a rural teaching hospital in South Africa. Journal of Psychology in Africa, 12(2):163-181.

RUESCH, J \& BATESON, G 1987: Communication: the social matrix of psychiatry. New York: WW Norton.

SCHOENBERG, NE 1997: A convergence of health beliefs: an "ethnography of adherence" of African-American rural elders with hypertension. Human Organization, 56(2):174-181.

SEEDAT, YK; SEEDAT, MA \& HACKLAND, DB 1982: Prevalence of hypertension in urban and rural Zulus. Journal of Epidemiology and Community Health, 36(2):256-261.

STEPTOE, A \& WARDLE, J 1992: Cognitive predictors of health behaviour in contrasting regions of Europe. British Journal of Clinical Psychology, 31(3):485-502.

STEYN, K; FOURIE, J \& BRADSHAW, D 1992: The impact of chronic diseases of lifestyle and their major risk factors on mortal- ity in South Africa. South African Medical Journal, 82(2):227231.

STEYN, K; FOURIE, J; LOMBARD, C; KATZENELLENBOGEN, J; BOURNE, L \& JOOSTE P 1996: Hypertension in the black community of the Cape Peninsula, South Africa. East African Medical Journal, 73(7):758-763.

UNGER, T 1995: Patient-doctor interactions in hypertension. Journal of Human Hypertension, 9(1):41-5.

WEIR, MR; MAIBACH, EW; BAKRIS, GL; BLACK, HR; CHAWLA, P; MESSERLI, FH; NEUTEL, JM \& WEBER 2000: Implications of a health lifestyle and medication analysis for improving hypertension control. Archives of Internal Medicine, 160(4):481-90. WHO 1993: Improving adverence behaviour with treatment regimens. Geneva: author. 
Appendix I: Transcription analysis of physician-patient communication

\begin{tabular}{|c|c|c|c|c|c|}
\hline Message given & Type of message given & $\begin{array}{l}\text { Number of } \\
\text { messages } \\
\text { given }\end{array}$ & Message recalled & $\begin{array}{l}\text { Type of message } \\
\text { recollected }\end{array}$ & $\begin{array}{l}\text { Number of } \\
\text { messages } \\
\text { recollected }\end{array}$ \\
\hline $\begin{array}{l}\text { \#19 -you have hypertension } \\
\text {-we will start you on treatment. } \\
\text {-in a situation like this you can } \\
\text { suffer from stroke, heart failure or } \\
\text { kidney disease. } \\
\text {-adhere to treatment } \\
\text {-come back when we say you } \\
\text { should come } \\
\text {-reduce salt in you diet and } \\
\text { alcohol if you are taking it. }\end{array}$ & $\begin{array}{l}\text { Diagnosis, treatment, } \\
\text { consequences, come for } \\
\text { follow-up, advice on diet \& } \\
\text { substances. }\end{array}$ & 6 & $\begin{array}{l}\text { The doctor told me to } \\
\text { reduce alcohol, } \\
\text { honour appointments } \\
\text { and take medication } \\
\text { everyday. }\end{array}$ & $\begin{array}{l}\text { Dietary, follow up \& } \\
\text { treatment. }\end{array}$ & 3 \\
\hline $\begin{array}{l}\text { \#18 -come for regular check-ups } \\
\text {-High blood can develop into } \\
\text { further complications like heart } \\
\text { failure, stroke and renal failure } \\
\text {-Take treatment regularly } \\
\text {-Hypertension cannot be cured } \\
\text {-Reduce drinking, smoking and } \\
\text { salt in your diet } \\
\text {-you are suffering from } \\
\text { hypertensive heart disease. }\end{array}$ & $\begin{array}{l}\text { Follow-up, consequences, } \\
\text { importance of treatment, } \\
\text { lifestyle modification (reduce } \\
\text { salt in meals, stop drinking } \\
\text { \& smoking), diagnosis }\end{array}$ & 6 & $\begin{array}{l}\text { Stop drinking, } \\
\text { smoking and reduce } \\
\text { salt in meals. }\end{array}$ & $\begin{array}{l}\text { Lifestyle } \\
\text { modification }\end{array}$ & 1 \\
\hline $\begin{array}{l}\text { \#35 -You've high blood } \\
\text {-stop eating salt and fat(remove } \\
\text { visible fat on meat) } \\
\text {-High blood can cause you a } \\
\text { stroke } \\
\text {-stop smoking \& drinking. }\end{array}$ & $\begin{array}{l}\text { Diagnosis, lifestyle } \\
\text { modification (diet and use of } \\
\text { substances) }\end{array}$ & 3 & $\begin{array}{l}\text {-I have high blood } \\
\text {-Stop eating salt and } \\
\text { fatty food } \\
\text {-stop smoking }\end{array}$ & $\begin{array}{l}\text { Diagnosis, lifestyle } \\
\text { modification. }\end{array}$ & 3 \\
\hline $\begin{array}{l}\# 15 \text {-Did any of your parents } \\
\text { have high blood } \\
\text {-You have high blood pressure } \\
\text {-you will be on treatment for the } \\
\text { rest of your life. } \\
\text {-reduce salt and fat in your meals } \\
\text {-reduce your body } \\
\text {-come back after a month }\end{array}$ & $\begin{array}{l}\text { Family history, lifestyle } \\
\text { modification (dietary), } \\
\text { diagnosis, duration of } \\
\text { treatment, follow-up. }\end{array}$ & 6 & $\begin{array}{l}\text {-I have high blood } \\
\text {-stop eating salty, } \\
\text { sugary and fatty } \\
\text { foods. } \\
\text {-I should come back } \\
\text { on the } 27 \text { th January } \\
2000\end{array}$ & $\begin{array}{l}\text { Diagnosis, lifestyle } \\
\text { modification } \\
\text { (dietary), follow-up. }\end{array}$ & 3 \\
\hline $\begin{array}{l}\text { \#8 -You have high blood } \\
\text { pressure } \\
\text {-You will take treatment for the } \\
\text { rest of your life } \\
\text {-Never stop taking medication } \\
\text { even if you feel better } \\
\text {-I will send you to the dietician } \\
\text { who will tell you what to eat and } \\
\text { what not to eat } \\
\text {-You are not supposed to run out } \\
\text { of medication } \\
\text {-Come back when medication is } \\
\text { finished }\end{array}$ & $\begin{array}{l}\text { Diagnosis, duration of } \\
\text { medication, dietary, follow- } \\
\text { up, importance of taking } \\
\text { medication }\end{array}$ & 6 & $\begin{array}{l}\text {-Continue taking } \\
\text { treatment } \\
\text {-Come to hospital } \\
\text { when medication is } \\
\text { finished }\end{array}$ & $\begin{array}{l}\text { Importance of } \\
\text { taking medication, } \\
\text { follow-up }\end{array}$ & 2 \\
\hline
\end{tabular}




\begin{tabular}{|c|c|c|c|c|c|}
\hline $\begin{array}{l}\text { \#9 -l'm asking you to stop eating } \\
\text { salt } \\
\text {-You will take medication for the } \\
\text { rest of your life. } \\
\text {-If you stop taking pills you will } \\
\text { have a stroke } \\
\text {-Go to the clinic for check-ups } \\
\text { and if medication is finished } \\
\text { come to hospital } \\
\text {-High blood pressure causes } \\
\text { heart failure }\end{array}$ & $\begin{array}{l}\text { Lifestyle modification } \\
\text { (dietary), duration of taking } \\
\text { medication, consequences } \\
\text { of HBP, follow-up. }\end{array}$ & & $\begin{array}{l}\text {-Cut down on salt } \\
\text {-Follow a healthy diet } \\
\text { (fruits \&vegetables) } \\
\text {-Take medication for } \\
\text { the rest of my life }\end{array}$ & $\begin{array}{l}\text { Lifestyle } \\
\text { modification } \\
\text { (dietary), duration } \\
\text { of taking treatment. }\end{array}$ & 2 \\
\hline $\begin{array}{l}\# 11 \text {-We are going to start you } \\
\text { on treatment of HBP today } \\
\text {-HBP can damage heart, brain \& } \\
\text { kidneys -take treatment } \\
\text {-come back monthly for } \\
\text { medication } \\
\text {-reduce amount of salt in your } \\
\text { meals } \\
\text {-Cut down on alcohol } \\
\text {-the treatment will make you } \\
\text { pass a lot of urine frequently so } \\
\text { don't be surprised }\end{array}$ & $\begin{array}{l}\text { Diagnosis, treatment, } \\
\text { consequences of HBP, } \\
\text { follow- ups, lifestyle } \\
\text { modification (dietary \& } \\
\text { alcohol), possible side } \\
\text { effects of treatment }\end{array}$ & 7 & $\begin{array}{l}\text {-I have high blood } \\
\text { pressure } \\
\text {-HBP can damage } \\
\text { heart, brain \& kidneys } \\
\text {-I should take } \\
\text { treatment and come } \\
\text { to hospital monthly } \\
\text {-I should also cut } \\
\text { down on salt and fatty } \\
\text { food. }\end{array}$ & $\begin{array}{l}\text { Diagnosis, } \\
\text { consequences of } \\
\text { HBP, stick to } \\
\text { treatment, come for } \\
\text { follow up and } \\
\text { collection of } \\
\text { medication, lifestyle } \\
\text { modification } \\
\text { (dietary) }\end{array}$ & 4 \\
\hline $\begin{array}{l}\# 10 \text {-l've realised that you've } \\
\text { hypertension } \\
\text {-The bottom line is you should } \\
\text { cut down on smoking \& drinking } \\
\text {-come back to see a doctor and } \\
\text { honour the appointment } \\
\text {-take you medication everyday } \\
\text {-Cut down on salt and fatty foods }\end{array}$ & $\begin{array}{l}\text { Diagnosis, lifestyle } \\
\text { modification (dietary, } \\
\text { substances), honour } \\
\text { appointments, treatment, }\end{array}$ & 5 & $\begin{array}{l}\text {-I should stop eating } \\
\text { salt } \\
\text {-stop drinking/ } \\
\text { smoking - stop eating } \\
\text { fatty foods } \\
\text {-have hypertension } \\
\text { and he will give me } \\
\text { the pills for it }\end{array}$ & $\begin{array}{l}\text { Lifestyle } \\
\text { modification } \\
\text { (dietary, } \\
\text { substances), } \\
\text { diagnosis, } \\
\text { treatment }\end{array}$ & 2 \\
\hline
\end{tabular}

